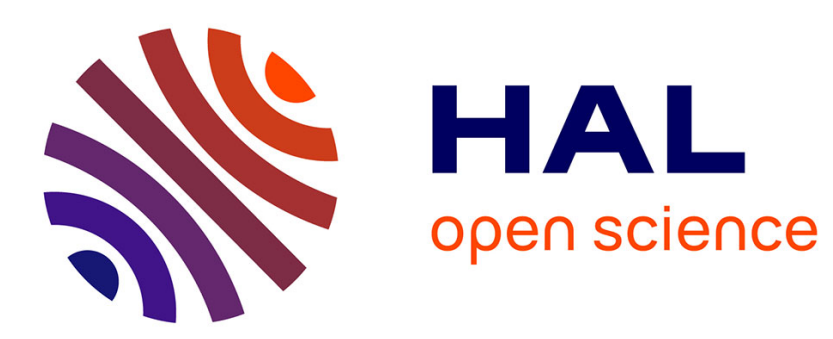

\title{
Effects of the anthelmintic drug PF1022A on mammalian tissue and cells
}

R. Dornetshuber, M.R. Kamyar, P. Rawnduzi, I. Baburin, K. Kouri, E. Pilz, T. Hornbogen, R. Zocher, W. Berger, R. Lemmens-Gruber

\section{- To cite this version:}

R. Dornetshuber, M.R. Kamyar, P. Rawnduzi, I. Baburin, K. Kouri, et al.. Effects of the anthelmintic drug PF1022A on mammalian tissue and cells. Biochemical Pharmacology, 2009, 77 (8), pp.1437. 10.1016/j.bcp.2009.01.005 . hal-00493486

\section{HAL Id: hal-00493486 \\ https://hal.science/hal-00493486}

Submitted on 19 Jun 2010

HAL is a multi-disciplinary open access archive for the deposit and dissemination of scientific research documents, whether they are published or not. The documents may come from teaching and research institutions in France or abroad, or from public or private research centers.
L'archive ouverte pluridisciplinaire HAL, est destinée au dépôt et à la diffusion de documents scientifiques de niveau recherche, publiés ou non, émanant des établissements d'enseignement et de recherche français ou étrangers, des laboratoires publics ou privés. 


\section{Accepted Manuscript}

Title: Effects of the anthelmintic drug PF1022A on mammalian tissue and cells

Authors: R. Dornetshuber, M.R. Kamyar, P. Rawnduzi, I. Baburin, K. Kouri, E. Pilz, T. Hornbogen, R. Zocher, W. Berger, R. Lemmens-Gruber

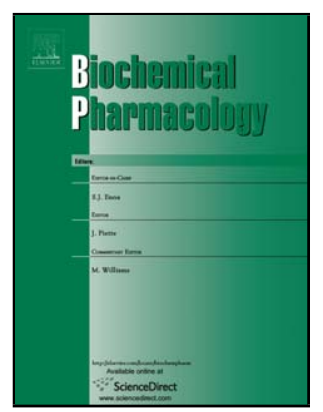

PII: S0006-2952(09)00025-2

DOI: doi:10.1016/j.bcp.2009.01.005

Reference: BCP 10064

To appear in: $\quad B C P$

Received date: $\quad$ 28-11-2008

Revised date: $\quad$ 7-1-2009

Accepted date: $\quad 8-1-2009$

Please cite this article as: Dornetshuber R, Kamyar MR, Rawnduzi P, Baburin I, Kouri K, Pilz E, Hornbogen T, Zocher R, Berger W, Lemmens-Gruber R, Effects of the anthelmintic drug PF1022A on mammalian tissue and cells, Biochemical Pharmacology (2008), doi:10.1016/j.bcp.2009.01.005

This is a PDF file of an unedited manuscript that has been accepted for publication. As a service to our customers we are providing this early version of the manuscript. The manuscript will undergo copyediting, typesetting, and review of the resulting proof before it is published in its final form. Please note that during the production process errors may be discovered which could affect the content, and all legal disclaimers that apply to the journal pertain. 


\section{Effects of the anthelmintic drug PF1022A on mammalian tissue and cells}

R. Dornetshuber ${ }^{1,2}$, M.R. Kamyar ${ }^{1}$, P. Rawnduzi ${ }^{1}$, I. Baburin ${ }^{1}$, K. Kouri ${ }^{1}$, Pilz E. ${ }^{1}$, T.

Hornbogen $^{3}$, R. Zocher ${ }^{3}$, W. Berger ${ }^{2}$, R. Lemmens-Gruber ${ }^{1}$

${ }^{1}$ Department of Pharmacology and Toxicology, University of Vienna, Althanstr. 14, A-1090

Vienna, Austria

${ }^{2}$ Institute of Cancer Research, Department of Medicine I, Borschkegasse 8a, Medical

University of Vienna, 1090 Vienna, Austria.

${ }^{3}$ Technical University of Berlin, Franklinstr. 29, D-10587 Berlin, Germany

\section{Corresponding author:}

Rosa Lemmens-Gruber

Department of Pharmacology and Toxicology, University of Vienna

Althanstr. 14

A-1090 Vienna

Austria

rosa.lemmens@univie.ac.at

Tel. $+43-1-4277-55325$

FAX $+43-1-4277-9553$

\section{Keywords:}

PF1022A, anthelmintics, ionophore, cytotoxicity, apoptosis 


\begin{abstract}
Nematode infections cause human morbidity and enormous economic loss in livestock. Since resistance against currently available anthelmintics is a worldwide problem, there is a continuous need for new compounds. The cyclooctadepsipeptide PF1022A is a novel anthelmintic that binds to the latrophilin-like transmembrane receptor important for pharyngeal pumping in nematodes. Furthermore, PF1022A binds to GABA receptors, which might contribute to the anthelmintic effect. Like other cyclodepsipeptides, PF1022A acts as an ionophore. However, no correlation between ionophoric activity and anthelmintic properties was found. This is the first study describing the effect of PF1022A on mammalian cells and tissues. While channel-forming activity was observed already at very low concentrations, changes in intracellular ion concentrations and reduction of contractility in isolated guinea-pig ileum occurred at multiples of anthelmintically active concentrations. PF1022A did not induce necrotic cell death indicated by complete lack of cellular lactate dehydrogenase release. In contrast, apoptosis induction via the mitochondrial pathway was suggested for long-term drug treatment at high concentrations due to numerous apoptotic morphological changes as well as mitochondrial membrane depolarisation. Short time effects were based on cell cycle blockade in $\mathrm{G}_{0} / \mathrm{G}_{1}$ phase. Additionally, the cell cycle and apoptosis regulating proteins $\mathrm{p} 53, \mathrm{p} 21$ and bax, but not Bcl-2 were shown to impact on PF1022Ainduced cytotoxicity. However, since PF1022A-induced cytotoxicity was found at drug concentrations higher than those used in anthelmintic treatment, it can be suggested that PF1022A intake might not impair human or animal health. Thus, PF1022A seems to be a safe alternative to other anthelmintic drugs.
\end{abstract}




\section{Introduction}

Nematode infections are a major cause of human morbidity and mortality in tropic and temperate climates [1]. Moreover, these pathogenes cause enormous economic loss in cattle, horses, pigs and sheep [2,3]. However, resistance against the major currently available anthelmintics has increasingly become a worldwide problem [4]. Therefore, new compounds with different modes of action are needed to manage the problem of resistance. The 24membered N-methylated cyclooctadepsipeptide PF 1022A belongs to a novel class of anthelmintic agents with potent broadspectrum anthelmintic activity and low toxicity in animals $[5,6,7,8,9]$. Additionally this drug was found to be a good candidate for the treatment of human angiostrongyliasis [10].

PF1022A is a secondary metabolite of the fungus imperfectus Mycelia sterilia (Rosellinia sp.) isolated from the plant Camellia japonica [5]. So far, the nonribosomal N-methylcyclooctadepsipeptide synthetase responsible for PF1022A biosynthesis has been isolated and characterized [11]. Consequently, this discovery allows the development of new N-methylcyclooctadepsipeptide-derived compounds [12]. PF1022A serves as starting material for the synthesis of semi-synthetic cyclooctadepsipeptide derivatives with improved anthelmintic potency and broadspectrum activity $[13,14,15,16]$. Meanwhile, also total synthesis of cyclooctadepsipeptides has been accomplished [17, 18, 19, 20, 21, 22]. With regard to the molecular mechanisms underlying its anthelmintic activity, PF1022A has been shown to bind to the amine terminus of the 110-kDa heptahelical, latrophilin-like transmembrane receptor HC-110R, isolated from Haemonchus contortus (Rudolphi). This receptor has an important regulatory function on pharyngeal pumping in nematodes. By binding to this receptor, PF1022A induces an influx of external $\mathrm{Ca}^{2+}$ into the cell [23], consequently affecting several presynaptic signal transduction pathways [24]. Due to this effect, treatment with PF1022A as well as the semi-synthetic emodepside causes worm 
paralysis $[24,25]$. These modes of action are different from the mechanisms of known anthelmintics like benzimidazoles, imidazothiazoles, tetrahydropyrimidines and macrocyclic lactones [26]. Thus, these new drugs might solve the increasing problem of resistance development against available anthelmintics. Indeed, PF1022A and emodepside were effective in benzimidazole-, levamisol- and ivermectin-resistant populations of Haemonchus contortus in sheep when applied orally, subcutaneously or intravenously. Additionally, they showed activity in ivermectin-resistant Cooperia oncomorpha population in cattle [3]. Furthermore, in binding studies it could be demonstrated that PF1022A binds to GABA receptors in nematodes, which might contribute to the anthelmintic effect [27]. PF1022A acts as an ionophore in planar lipid bilayers like other cyclodepsipeptides, however, testing structurally related derivates revealed no correlation between ionophoric activity and anthelmintic properties [28].

However, at least to our knowledge, no data describing the effect of PF1022A on mammalian cells and tissues are published so far. PF1022A is structurally related to cyclohexadepsipeptides of the enniatin-type for which synergistic effects on antifungal drug activity were described [29,30]. Moreover, potent cytostatic and cytotoxic effects against diverse cancer cell types [31, 32,33], antiangiogenic activity [34] as well as anthelmintic properties [35] could be demonstrated for these structurally related cyclohexadepsipeptides. Aim of this study was to investigate the effect of PF1022A on force of contraction in isolated guinea-pig ileum, its electrophysiological properties and the resulting impacts on cell homeostasis. Moreover, PF1022A-induced cytotoxic modes of action were elucidated in mammalian cells. 


\section{Materials and Methods}

\subsection{Test compound}

PF1022A was kindly supplied by Bayer AG, Germany. The compound is poorly soluble in water, therefore a stock solution with Tween $80: \mathrm{MeOH}=1: 2$ (Sigma-Aldrich, Vienna, Austria) was prepared. This solution was further diluted to the nutrient solution at the final concentration.

\subsection{Cell lines}

The following human cell lines were used in this study: the epidermal carcinoma-derived cell line KB-3-1 (generously donated by Dr. Shen, Bethesda, USA) [36], and the colon carcinoma cell line CaCo-2 (American Tissue Culture Collection), the colon carcinoma cell model HCT116 and respective sublines with deleted p53, p21, or bax genes were generously donated by Dr. Vogelstein, John Hopkins University, Baltimore [37, 38, 39], and the Bcl-2-negative non-small cell lung cancer cell line A549 and its bcl-2 pBabe/Puro-transfected subline [31]. HCT116 cell lines were grown in McCoy's culture medium, Caco-2 cells in MEME, and KB3-1 as well as A549 cells and the transfected subline in RPMI 1640 medium. All culture media were purchased from Sigma-Aldrich GmbH (St. Louis, MO) and supplemented with 10\% fetal calf serum (PAA, Linz, Austria). Cultures were periodically checked for Mycoplasma contamination.

\subsection{Contractility measurement}

The effect of PF1022A on force of contraction $\left(f_{c}\right)$ of isolated terminal ilea of the guinea pig was studied as previously described [40]. All chemicals were purchased by Sigma-Aldrich 
(Vienna, Austria). The test compound was added cumulatively to the bathing solution in rising concentrations every $30 \mathrm{~min}$ when a steady-state effect has been reached.

\subsection{Ionophoric activity - single channel current}

Electrical activity was studied on $\mathrm{CaCo}-2$ cells at room temperature $\left(19-22^{\circ} \mathrm{C}\right)$ as previously described [40, 48]. Chemicals for pipette and bathing solutions were supplied by SigmaAldrich (Vienna, Austria). After a control period of 15 min during which no electrical activity could be observed, PF1022A was added to the bathing solution. The wash-in phase lasted about 1 to 2 min until single channel current could be detected. The same experimental protocol $\left(E_{h}=-60,-40,-20,0,+20,+40,+60 \mathrm{mV}\right)$ was applied as during control recordings. Electrophysiological measurements were carried out with an Axopatch-1D patch clamp amplifier (Axon Instruments, CA) at a cut-off frequency $(-3 \mathrm{~dB})$ of $2 \mathrm{kHz}$. Currents were filtered at $5 \mathrm{kHz}$ with a dual variable filter (VBF 8, Kemo Ltd, Beckenham, Kent, U.K.), digitized via an AD converter (TL-1 interface, Axon Instruments, CA) and sampled at 5-10 kHz. Data acquisition and storage were processed directly to a PC equipped with pCLAMP 6 software (Axon Instruments, CA). Single channel analysis was performed with the ASCD software (G. Droogmans, Leuven, Belgium).

\subsection{Two-microelectrode voltage clamp studies - $\mathrm{GABA}_{\mathrm{A}}$ receptor}

Stage V-VI oocytes from Xenopus laevis were prepared and cRNA injected as previously described $[41,42]$. On the $2^{\text {nd }}$ day after cRNA injection, electrophysiological experiments were performed by the two-microelectrode voltage clamp method using of a TURBO TEC 01C amplifier (npi electronic $\mathrm{GmbH}$, Tamm, Germany) at a holding potential of $-70 \mathrm{mV}$. The bath solution contained $90 \mathrm{mM} \mathrm{NaCl}, 1 \mathrm{mM} \mathrm{KCl}, 1 \mathrm{mM} \mathrm{MgCl}_{2}, 1 \mathrm{mM} \mathrm{CaCl}_{2}$ and $5 \mathrm{mM}$

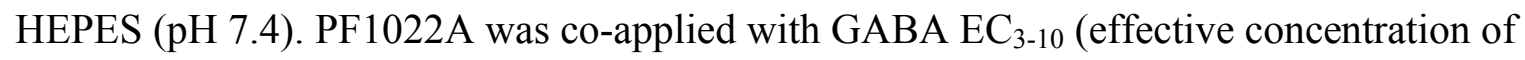


GABA that induces 3-10\% of maximal GABA-evoked current) by means of an automated fast perfusion system according to [43]. Percent potentiation of $I_{\mathrm{GABA}}$ by the PF1022A was calculated using formula: $(\mathrm{R} / \mathrm{C}) * 100 \%$, where $\mathrm{R}$ is the amplitude of the chloride current evoked by co-application of control $\mathrm{GABA} \mathrm{EC}_{3-10}$ and the indicated concentration of the compound, and $\mathrm{C}$ is the amplitude of the chloride current evoked by application of control GABA EC $_{3-10}$ alone.

\subsection{Fluorescence imaging}

Caco-2 cells were loaded with $1 \mu \mathrm{M}$ FURA $2 \mathrm{AM}$ and an equivalent concentration of Pluronic $20 \%$ in DMSO at room temperature $\left(18-23^{\circ} \mathrm{C}\right)$ for $30-45$ min. Fluorescent dye and Pluronic were procured from Molecular Probes (Leiden, The Netherlands). After washout cells were allowed to hydrolyze the dye for 30 minutes to one hour, and experiments were performed as previously described [47]. Ratiometric measurements were realized following background subtraction with the Axon Imaging Workbench 2.2 software (Axon Instruments, CA) averaging 2 frames. Results are presented as the relative change $\left(-\Delta F / F_{0}\right)$ of the $F_{340} / F_{380}$ signal.

\subsection{Cell viability assays}

KB-3-1 cells were seeded $\left(2 \times 10^{4}\right.$ cells $\left./ \mathrm{ml}\right)$ in 96 -well plates and were allowed to recover for $24 \mathrm{~h}$. Concentrations of PF1022A ranging from $0.5 \mu \mathrm{M}$ up to $10 \mu \mathrm{M}$ were applied with an incubation time of 24, 48 and $72 \mathrm{~h}$. The cytotoxic effect of PF1022A was determined with an MTT-based vitality assay (EZ4U, Biomedica, Vienna, Austria) as described previously [31]. Moreover, to study the reversibility of the cytotoxic PF1022A effect, after an incubation time of $1,2,4,6,8,24$ and $48 \mathrm{~h}$ the test compound was removed from the wells and substituted by 
fresh medium. After a total incubation period of $72 \mathrm{~h}$ the EZ4U assay was performed and data were evaluated by means using the GraphPadPrism 4 software.

\subsection{Lactate dehydrogenase release assay}

The release of lactate dehydrogenase (LDH) from the cytosol, which indicates loss of membrane integrity and is further associated with necrotic cell death, was studied with a cytotoxicity detection kit (Roche, Basel, Switzerland). Adherent KB-3-1 cells $\left(2 \times 10^{4}\right.$ cells $\left./ \mathrm{ml}\right)$ were incubated in 96-well plates for $24 \mathrm{~h}$ with PF1022A $(0.5 \mu \mathrm{M}-10 \mu \mathrm{M})$. Afterwards, from each well $100 \mu$ l of the supernatant was transferred to a 96-well microplate and incubated for $20 \mathrm{~min}$ at $37^{\circ} \mathrm{C}$ with reagent solution of the kit according to the manuel. Finally, absorbance was measured with a microplate reader, set at $490 \mathrm{~nm}$ and $620 \mathrm{~nm}$ as reference.

\subsection{DAPI Staining}

$1 \times 10^{5} \mathrm{~KB}-3-1$ cells/well were treated in 6 well plates with $2.5-10 \mu \mathrm{M}$ PF1022A for $24 \mathrm{~h}$ and $48 \mathrm{~h}$, respectively. Subsequently, cells were harvested, cytospins were prepared, and apoptosis was evaluated by staining with 4',6-diamidino-2-phenylindole (DAPI) containing antifade solution (Vector Laboratories, Inc., Burlingame, CA). The nuclear morphology of cells was examined with a Leica DMRXA fluorescence microscope (Leica Mikroskopie and System, Wetzlar,Germany) equipped with appropriate epifluorescence filters and a COHU chargecoupled device camera. The rate of apoptosis was determined as the percentage of apoptotic nuclei of at least 500 nuclei/experimental group.

\subsection{Cell cycle analysis}

Adherent KB-3-1 (5x10 cells/well) were incubated in 6-well plates at $37^{\circ} \mathrm{C}$ for 24 or $48 \mathrm{~h}$ with $0.5,1,2.5,5$ and $10 \mu \mathrm{M}$ PF1022A. Cell cycle progression was analysed by flow 
cytometry using FACS Calibur (Becton Dickinson, Palo Alto CA) as described [44]. Cell the resulting DNA histograms.

\subsection{Detection of mitochondrial membrane potential}

KB-3- 1 cells $\left(5 \times 10^{6}\right.$ cells/well) were exposed to $1,2.5,5$ and $10 \mu \mathrm{M}$ PF1022A for $24 \mathrm{~h}$ before cell staining was performed with the fluorescent dye 5,5',6,6'-tetrachloro-1,1',3',3'-tetraethylbenzimidazolylcarbocyanine iodide (JC-1; Mitochondrial Membrane Potential detection Kit; Stratagene, La Jolla, CA, USA) as described [31, 44].

\subsection{Statistical analysis}

Values are expressed as means \pm S.E. where appropriate. Significance was calculated with Student's t-test for paired $\left(\mathrm{f}_{\mathrm{c}}\right)$ and unpaired observations. Statistical significance was determined at levels of $\mathrm{P}<0.05, \mathrm{P}<0.01$ and $\mathrm{P}<0.001$.

\section{Results}

\subsection{Effect on force of contraction}

Isometrically measured $\mathrm{f}_{\mathrm{c}}$ of isolated, pre-contracted $(60 \mathrm{mM} \mathrm{KCl})$ terminal ilea of the guinea pig was concentration-dependently ( 0.1 to $30 \mu \mathrm{M}$ PF1022A) decreased with an $\mathrm{IC}_{50}$ of $25 \pm 3$ $\mu \mathrm{M}(\mathrm{n}=3)$. At solvent concentrations up to $3.5 \mu \mathrm{l}$ methanol/Tween in $28 \mathrm{ml}$ nutrient solution, which corresponds to the solvent concentration at $10 \mu \mathrm{M}$ PF1022A, no effect on contractility of isolated smooth muscle preparations was observed. At $10 \mu \mathrm{l}$ methanol/Tween in $28 \mathrm{ml}$ nutrient solution, that is the solvent concentration at $30 \mu \mathrm{M}$ PF $1022 \mathrm{~A}, \mathrm{f}_{\mathrm{c}}$ was decreased by 
$4.4 \%(n=3)$. Therefore, results obtained with $30 \mu \mathrm{M}$ PF1022A were corrected for this solvent induced decrease in contractility. Reduction of $f_{c}$ was only significant at $30 \mu \mathrm{M}$ PF1022A $(\mathrm{n}=3, \mathrm{P}<0.05)$. At the anthelmintically active concentration of $1 \mu \mathrm{M}$ PF1022A [6], the decrease of $f_{c}$ from the control value of $17.8 \pm 2.6 \mathrm{mN}$ to $15.9 \pm 2.2 \mathrm{mN}$ was not significant $(n=3, P>0.05)$.

\subsection{Pore-forming activity}

After a control period of 15 min during which no electrical activity could be observed at holding potentials between -60 and $+60 \mathrm{mV}$, PF1022A was added to the bathing solution. One to two minutes after addition of $1 \mu \mathrm{M}$ PF1022A pore forming activity was detected in inside-out patches of Caco- 2 cells with mono- and divalent cations $\left(\mathrm{Na}^{+}, \mathrm{K}^{+}, \mathrm{Ca}^{2+}\right)$ as the charge carriers. Higher PF1022A concentrations achieved similar effects, but faster onset of action and multiple channel openings (Fig. 1A). Washout of the substance was not effective indicating permanent incorporation into the cell membrane.

The experimental reversal potentials for potassium $(n=3)$ and sodium $(n=3)$ were comparable to the theoretical values for the ionic equilibrium potential calculated according to the Nernst equation. Further, current amplitudes did not vary when aspartate was substituted by chloride in the $\mathrm{K}^{+}$and $\mathrm{Na}^{+}$bathing solutions in equal cation molarity $(\mathrm{n}=3)$, also indicating the channel's cationic selectivity.

Current to voltage relationships for potassium, sodium and calcium currents presented a symmetrical behaviour upon hyper- and depolarization, rectifying at potentials higher than $20 \mathrm{mV}$ and $+20 \mathrm{mV}$. Single channel conductance was therefore estimated in the linear range of $-20 \mathrm{mV}$ to $+20 \mathrm{mV}$ and was calculated for $\mathrm{K}^{+}$at $39.3 \pm 2.8 \mathrm{pS}(\mathrm{n}=5)$, for $\mathrm{Na}^{+}$at $52.3 \pm 3.0$ $\mathrm{pS}(\mathrm{n}=5)$ and for $\mathrm{Ca}^{2+}$ at $50.5 \pm 2.2 \mathrm{pS}(\mathrm{n}=3)$. 
Probability density functions for open times of the PF1022A channel conducting potassium, sodium or calcium ions at potentials ranging from -60 to $+60 \mathrm{mV}$ could be fitted with one exponential. The kinetics of the openings at those potentials was not significantly $(\mathrm{P}>0.05)$ affected by voltage. Further, time constants for open times did not significantly differ for $\mathrm{Na}^{+}$, $\mathrm{K}^{+}$and $\mathrm{Ca}^{2+}(\mathrm{P}>0.05)$. Open state probability was independent of voltage, however, varying markedly in different patches and also within one patch with time. Openings occurred usually in bursts of fast flickerings, which alternated with periods of electrical inactivity. For $\mathrm{Ca}^{2+}$ conducting channels these periods without electrical activity were almost twice the duration of those with the studied monovalent cations.

\subsection{Effect on intracellular ion concentration}

For studying the effect of PF1022A on intracellular calcium, sodium and potassium concentrations, the ionophores ionomycin, gramicidine and valinomycin ( $\mathrm{n}=3$ for each) were used as reference compounds. Although PF1022A incorporated into the cell membrane leading to conduction of calcium, sodium and potassium ions, for $\mathrm{Na}^{+}$ions no effect on the intracellular concentration was observed, while the intracellular $\mathrm{K}^{+}$and $\mathrm{Ca}^{2+}$ concentrations were changed. The effect of PF1022A on intracellular $\mathrm{Ca}^{2+}$ concentration, however, was weak compared to the control with ionomycin. Representative recordings are presented for $\mathrm{Ca}^{2+}$ in Figure $1 \mathrm{~B}$ and $\mathrm{C}$. Only a small increase in the intracellular $\mathrm{Ca}^{2+}$ concentration was caused by $100 \mu \mathrm{M}$ PF1022A (n=7) compared to $100 \mu \mathrm{M}$ ionomycin, while at $10 \mu \mathrm{M}$ PF1022A (a concentration causing multiple channel openings, see Fig. $1 \mathrm{~A}, \mathrm{n}=6)$ no changes in $\left[\mathrm{Ca}^{2+}\right]_{\mathrm{i}}$ were observed (data not shown). The effect on intracellular $\mathrm{K}^{+}$concentration is illustrated for $100 \mu \mathrm{M}$ PF1022A (E) and $100 \mu \mathrm{M}$ valinomycin (D) for two representative cells each. The effect on intracellular $\mathrm{K}^{+}$was more pronounced than on intracellular $\mathrm{Ca}^{2+}$, but still weak at 
concentrations that already caused multiple channel openings $(10 \mu \mathrm{M}, \mathrm{n}=6)$, and ineffective at $1 \mu \mathrm{M}$ PF1022A $(\mathrm{n}=5)$.

\subsection{Effect on chloride currents through $\mathrm{GABA}_{\mathrm{A}}$ receptors by $\mathrm{PF1022A}$}

As an anthelmintic effect via binding to the GABA receptor in nematodes was suggested [27], we also studied the electrophysiological effect of PF1022A on $\mathrm{GABA}_{\mathrm{A}}$ channels. An effect on this channel is of interest e.g. in respect to sedative side effects of the drug. At 1 and $10 \mu \mathrm{M}$ PF1022A, the potentiation of GABA-activated chloride current $\left(I_{\mathrm{GABA}}\right)$ through $\alpha 1 \beta 2 \gamma 2 \mathrm{~S}$ receptors was $20.8 \pm 11.2 \%(n=4)$ and $78.2 \pm 16.1 \%(n=6)$, respectively. However, an effect of PF1022A on $\mathrm{GABA}_{\mathrm{A}}$ can be excluded, because the solvent-induced increase in $\mathrm{I}_{\mathrm{GABA}}$ was $70.8 \pm 39.4 \%$ at a solvent concentration which corresponds to the concentration present at 10 $\mu \mathrm{M}$ PF1022A.

\subsection{Effects of PF1022A on cell proliferation and viability}

To investigate the impact of the anthelmintic drug PF1022A on human cell proliferation, dose-response curves $(0.5-10 \mu \mathrm{M})$ were established in human KB-3-1 cells using different exposure times. Based on MTT assays an increased cell proliferation was observed in KB-3-1 cells after 24 and $48 \mathrm{~h}$ exposure to PF1022A concentrations $\leq 1 \mu \mathrm{M}$ (Fig. 2). The maximal increase in cell growth (1.25-fold) was observed after $24 \mathrm{~h}$ incubation with $0.5 \mu \mathrm{M}$ PF1022A. At higher PF1022A concentrations the number of viable cells decreased concentration dependently with an $\mathrm{IC}_{50}$ of $8.1 \mu \mathrm{M}(24 \mathrm{~h}), 6.6 \mu \mathrm{M}(48 \mathrm{~h})$ and $5.9 \mu \mathrm{M}(72 \mathrm{~h})$, respectively. Moreover, recovery of cells exposed for $1,2,4,6,8,24$ or $48 \mathrm{~h}$ to increasing PF1022A concentrations was studied after $72 \mathrm{~h}$. These experiments revealed enhanced cell proliferation at concentrations $\leq 2.5 \mu \mathrm{M}$ and short exposure times (1 to $8 \mathrm{~h}$ ). A maximum growth stimulation (1.3-fold growth) was obvious at $2 \mathrm{~h}$ treatment with $2.5 \mu \mathrm{M}$ PF1022A. However, 
in experiments with expanded drug exposure time ( 24 and $48 \mathrm{~h})$, no stimulating effect was observed (data not shown). This is in contrast to experiments without wash-out phase (Fig. 2). The cytotoxic effect at higher drug concentrations ( $>5 \mu \mathrm{M})$ and long time exposure (24 and $48 \mathrm{~h}$ ) did not differ significantly from data obtained without wash-out. This indicates potent cytotoxic effects of PF1022A at high concentrations (data not shown).

\subsection{Apoptosis induction by PF1022A}

To gain more insights into the PF1022A-induced cell death, LDH release from mitochondria to cytosol, which is indicative for necrotic cell death, was measured. Since no cytosolic LDH

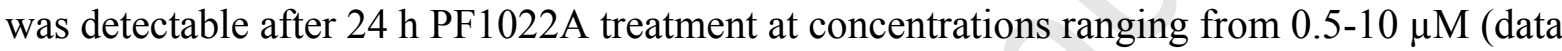
not shown), we hypothesized that the decrease in the number of viable cells was due to apoptotic cell death. This was further confirmed by results obtained by Dapi stainings of control and PF1022A-treated KB-3-1 cells. By direct counting under the microscope a concentration- and time-dependent increase of apoptotic nuclei was observed indicated by characteristic apoptotic features like cell shrinkage, chromatin condensation and apoptotic body formation. In more detail, after $24 \mathrm{~h}$ exposure to $2.5,5$ and $10 \mu \mathrm{M}$ PF $1022 \mathrm{~A}$ a relative minor increase in the number of apoptotic nuclei from $2 \%$ in the control to $4 \%, 12 \%$ and $14 \%$ was observed (Fig. 3A). In contrast, after $48 \mathrm{~h}$ treatment with the above mentioned PF1022A concentrations the proportion of apoptotic nuclei remarkably increased from $3 \%$ in the control to $6 \%, 15 \%$ and $36 \%$, respectively (Fig. $3 \mathrm{~B}$ ).

Since programmed cell death can be initiated via the so-called mitochondrial pathway which is based on depolarisation of the outer mitochondrial membrane, FACS analyses with JC-1stained KB-3-1 cells were performed. JC-1 is a lipophilic cation fluorescent dye, which can enter into intact mitochondria selectively [44]. While after $24 \mathrm{~h}$ exposure to $10 \mu \mathrm{M}$ PF1022A a moderate mitochondrial membrane depolarisation was shown $(12.4 \%$ of cells vs. $4.3 \%$ in 
control) this effect was distinctly enhanced after $48 \mathrm{~h}$ treatment (32\% of cells vs. control of 3\%) (Fig.4C). In contrast, PF1022A did not affect the mitochondrial membrane potential at concentrations $\leq 2.5 \mu \mathrm{M}$, independent of exposure time (data not shown).

\subsection{Impact of PF1022A on cell cycle distribution}

To further investigate whether PF1022A affect the cell cycle distribution flow cytometric analyses were performed in KB-3-1 cells and histograms were gated on live cells. PF1022A treatment caused a moderate concentration-dependent increase in the number of cells in $\mathrm{G}_{0} / \mathrm{G}_{1}$-phase after $24 \mathrm{~h}$ and $48 \mathrm{~h}$ (Fig. 4). This effect was distinct at concentrations $\geq 5 \mu \mathrm{M}$ as shown by an increase of cells in $\mathrm{G}_{0} / \mathrm{G}_{1}$-phase by $23 \%$ and $19 \%$ after 24 - and $48 \mathrm{~h}$ exposure, respectively. Additionally, after $24-$ and $48 \mathrm{~h}$ treatment with $10 \mu \mathrm{M}$ PF1022A a further increase was observed by $43 \%$ and $34 \%$, respectively. In accordance, the number of cells in the $\mathrm{S}$ - and $\mathrm{G}_{2} / \mathrm{M}$-phase significantly decreased at these concentrations

\subsection{Impact of apoptosis- and cell cycle-regulating proteins p53, p21, Bax, and Bcl-2 on} PF1022A-induced cell death.

To further investigate the mechanisms underlying PF1022A-induced cell death, the effect of apoptosis- and cell cycle regulating proteins was studied. For this purpose, HCT116 cells with disrupted p53, p21 or bax genes as well as A549 cells with stably overexpressing bcl-2 gene (A549/Bcl-2) were used. In general, in all tested cell lines a distinct cytotoxic effect was observed at high concentrations $(10 \mu \mathrm{M})$. Remarkably, deletion of p53 was accompanied with loss of sensitivity to high PF1022A concentrations (Tab. 1). Comparable effects were observed in HCT116 bax (-/-) cells (Tab. 1). In contrast, the cytotoxic effect of PF1022A was more prominent in HCT116 p21 (-/-) cells than in the respective parental cell clone (Tab. 1). 
Effects of PF1022A on cell growth of A549 with transfected Bc12 and the A549 vector control did not differ significantly from each other.

\section{Discussion}

The anthelmintic drug PF1022A is active against diverse worms when administered orally or parenterally. Depending on the species of worms and the host, helmints are paralysed in concentrations ranging from 1 to $10 \mathrm{mg} / \mathrm{kg}$ body weight $[8,26]$, which coincides with the in vitro activity at $1 \mu \mathrm{g} / \mathrm{ml}$ against Trichinella spiralis and Nippostrongylus brasiliensis [45] as well as the effect at $1 \mu \mathrm{M}$ PF1022A against Haemonchus contortus [6]. The lack of an effect on $\mathrm{f}_{\mathrm{c}}$ at $1 \mu \mathrm{M}$ and an estimated $\mathrm{IC}_{50}$ of $25 \mu \mathrm{M}$ for isolated guinea-pig ileum demonstrate that contractility is not reduced significantly at anthelmintic active concentrations. Consequently, the peristalsis which is necessary to transfer food through the gut should not be affected by the drug. Comparable to other cyclohexadepsipeptides [46, 47], PF1022A influenced the intracellular $\mathrm{Ca}^{2+}$ concentration in Caco-2 cells only at high drug concentrations $(\geq 30 \mu \mathrm{M})$. Sustained $\mathrm{Ca}^{2+}$ elevation usually results in dysfunction of the contractile mechanism, which might be the cause of the observed reduction in the force of contraction in isolated guinea pig ileum at high drug concentrations.

Results obtained from electrophysiological experiments give evidence that the cyclooctadepsipeptide PF1022A interacts with mammalian cells. The drug was shown to incorporate into cell membranes forming cation selective channels, similar to the cyclohexadepsipeptides beauvericin [48] and enniatin [40]. Patch clamp studies revealed that PF1022A manifests common traits of physiological ion channel behaviour such as unitary transitions in conductance levels characteristic for channels, selectivity, rectification, and 
conductances in the $\mathrm{pS}$ range. This strongly suggests that PF1022A is a potential channelforming ionophore. Moreover, formation of a sandwich complex can be postulated similar to the cyclohexadepsipeptides beauvericin [49] and enniatin [50]. Through such PF1022Ainduced membrane spanning pores, ions are able to diffuse at both directions following their electrochemical gradient. This conformation would allow the symmetry depicted in the current-voltage curves and the sort of electrostatic interaction that prevailed in our experiments, making the pore selective to cations. However, contrary to beauvericin and enniatin, the kinetics of the PF1022A-induced channel were not influenced by conducted cations. Although this ionophoric action was found already at very low drug concentrations, ion influx affected intracellular ion concentrations only minimally, even at high drug concentrations. Thus, these changes in intracellular ion concentrations might not contribute markedly to cellular toxicity. Apart from these findings, it has been already demonstrated that the ionophoric activity does not correlate with the anthelmintic potency of cyclooctadepsipeptides [28].

Besides the ionophoric activity, electrophysiological effects via modulation of the GABA current are discussed, as in binding studies it could be demonstrated that PF1022A binds to GABA receptors in nematodes, probably contributing to the anthelmintic effect [27]. Therefore, we tested whether PF1022A exerts any effect on $\mathrm{GABA}_{\mathrm{A}}$ receptors composed of $\alpha 1, \beta 2$ and $\gamma 2 \mathrm{~S}$ subunits, which might be of interest in terms of sedative side effects during anthelmintic therapy. Significant activation of the GABA current, however, was not observed. For the reason of diverse pharmacological properties of structurally related compounds, and in order to prove low cellular toxicity of PF1022A at anthelmintic concentrations, a panel of cytotoxicity tests was performed in mammalian cells. Cytotoxic effects after different exposure times to PF1022A occurred at micromolar concentrations but higher than the active anthelmintic concentrations. Since the results obtained in experiments with and without 
washout phase did not differ significantly at PF1022A concentrations $>5 \mu \mathrm{M}$ and only a small number of cells could recover, a potent cytotoxic effect of this cyclooctadepsipeptide was suggested at high concentrations. In contrast, at low anthelmintic concentrations $(0.5-1 \mu \mathrm{M})$ PF1022A significantly enhanced proliferation of the tumour cell line KB-3-1. Comparable effects were reported for the structurally related enniatins [31]. This growth stimulating activity was suggested to be based on compensatory mechanisms to enniatins-induced stress signals [31].

Regarding PF1022A-induced cytotoxicity, apoptosis induction via the mitochondrial pathway was suggested at least for long-term PF1022A treatment at high concentrations. This was based on a significant depolarisation of the mitochondrial membrane potential, which is an important step to trigger programmed cell death, after $48 \mathrm{~h}$ PF1022A treatment with $10 \mu \mathrm{M}$ [50]. Moreover, several characteristics of programmed cell death like cell shrinkage, chromatin condensation and apoptotic body formations were observed after $48 \mathrm{~h}$ drug treatment with $10 \mu \mathrm{M}$ PF1022A. Furthermore, the complete lack of cellular lactate dehydrogenase release indicative for necrotic cell death emphasizes the apoptotic activity of the anthelmintic drug. These results are comparable to the cytototoxic effects of the structurally related cyclohexadepsipeptides enniatins [31] and beauvericin [32, 33]. Moreover, since the ionophoric activity of these cyclic peptides was suggested to contribute to their potent cytotoxicity $[33,46,53]$, comparable modes of actions might be hypothesized for PF1022A. However, our study revealed that only high concentrations $(100 \mu \mathrm{M})$ of the cyclooctadepsipeptide PF1022A cause an increase in the intracellular $\mathrm{Ca}^{2+}$ levels. Thus, this effect does not seem to contribute markedly to cytotoxicity.

In addition to apoptosis induction, our study revealed that long-term but also short-term PF1022A treatment concentration-dependently led to cell cycle arrest in $\mathrm{G}_{0} / \mathrm{G}_{1}$ phase. Thus, the cytotoxic modes of actions of short-term PF1022A exposure might be based on a cell 
cycle blockade. Consistently, data obtained by DAPI staining revealed a significant reduction of countable nuclei compared to control after $24 \mathrm{~h}$ drug treatment. Moreover, cells with deleted cyclin-dependent kinase inhibitor p21 were more sensitive to PF1022A-induced cytotoxicity. This suggests that cell cycle blockade via p21 might rescue cells from PF1022Ainduced cell death as it was also suggested for the structurally related enniatins [31]. To further investigate the impact of PF1022A on apoptosis- and cell cycle-regulating proteins, HCT116 cells with disrupted p53, p21 or bax genes [37, 38, 39] and A549 cells transfected with Bcl-2 were used. In MTT assays, a small shift of cytotoxicity to higher PF1022A concentrations was observed in p53 and bax disrupted cells, whereas the apoptosis inhibitor Bcl-2 had no significant influence on PF1022A-induced cell death. Thus, our data suggest that PF1022A-induced mitochondrial membrane depolarisation occurs via a molecular mechanism involving p53-mediated apoptosis effects. This is in contrast to enniatins, which mediated apoptosis induction independent of either of these proteins, but activated the proapototic p53-downstream target bax at relatively low enniatin concentrations [31]. To conclude, data obtained with PF1022A in mammalian tissue and cells point to drug safety in terms of lower susceptibility of mammalian tissue compared to the paralysing effect in helmints. Moreover, due to the lack of an effect on $\mathrm{I}_{\mathrm{GABA}(\mathrm{A})}$ at anthelmintic concentrations no sedative side effects are to be expected. In addition, the drug PF1022A and its derivatives might be of interest to be studied in more detail in respect to anticancer activity. 


\section{References}

[1] Bundy DA, de Silva NR. Can we deworm this wormy world? Br Med Bull 1998;54:42132.

[2] Waller PJ. Anthelmintic resistance. Vet Parasitol 1997;72:391-412.

[3] von Samson-Himmelstjerna G, Harder A, Sangster NC, Coles GC. Efficacy or two cyclooctadepsipeptides, PF1022A and emodepsidde, against anthelmintic-resistant nematodes in sheep and cattle. Parasitology 2005;130:343-7.

[4] Geary TG, Sangster NC, Thompson DP. Frontiers in anthelmintic pharmacology. Vet Parasitol 1999;84:275-95.

[5] Sasaki T, Takagi M, Yaguchi T, Miyadoh S, Okada T, Koyama M. A new anthelmintic cyclodepsipeptide, PF1022A. J Antibiot (Tokyo) 1992;45:692-7.

[6] Conder GA, Johnson SS, Nowakovski DS, Blake TE, Dutton FE, Nelson SJ, et al. Anthelmintic profile of the cyclodepsipeptide PF1022A in in vitro and in vivo models. $\mathrm{J}$ Antibiot (Tokyo) 1995;48:820-3.

[7] Kachi S, Terada M, Hashimoto H. Effect of PF1022A on adult Angiostrongylus cantonensisin the pulmonary arteries and larvae migrating into the central nervous system in rats. Parasitol Res 1995; 81:631-7.

[8] von Samson-Himmelstjerna G, Harder A, Schmieder T, Kalbe J, Mencke N. In vivo activities of the new anthelmintic depsipeptide PF1022A. Parasitol Res 2000;86:194-9.

[9] Zahner H, Taubert A, Harder A, von Samson-Himmelstjerna G. Filaricidal efficacy of anthelmintically active cyclodepsipeptides. Int J Parasitol 2001;31:1515-2.

[10] Mentz MB, Graeff-Teixeira C. Drug trials for treatment of human angiostrongliasis. Rev Inst Med trop S Paulo 2003;45:179-4. 
[11] Weckwerth W, Miyamoto K, Iinuma K, Krause M, Glinski M, Storm T, et al. Biosynthesis of PF1022A and related cyclooctadepsipeptides. J Biol Chem 2000;275:17909-15.

[12] Krause M. Untersuchungen zur Biosynthese des Cyclooctadepsipeptids PF1022A. Dissertation TU Berlin 1998.

[13] Yanai K, Sumida N, Okakura K, Moriya T, Watanabe M, Murakami T. Para-position derivatives of fungal anthelmintic cyclodepsipeptides engineered with Streptomyces venezuelae antibiotic biosynthetic genes. Nat Biotechnol 2004;22:848-5.

[14] Jeschke P, Iinuma K, Harder A, Schindler M, Murakami T. Influence of the cyclooctadepsipeptide PF1022A and PF1022E as natural products on the design of the semi-synthetic anthelmintics such as emodepside. Parasitol Res 2005;97:511-6.

[15] Jeschke P, Harder A, Etzel W, Gau W, Thielking G, Bonse G, et al. Synthesis and anthelmintic activity of thioamide analogues of cyclic octadepsipeptides such as PF1022A. Pest Manag Sci 2001;57:1000-6.

[16] Jeschke P, Harder A, von Samson-Himmelstjerna G, Etzel W, Gau W, Thielking G, et al. Synthesis of anthelmintically active N-methylated amidoxime analogues of the cyclic octadepsipeptide PF1022A. Pest Manag Sci 2002;58:1205-15.

[17] Dyker H, Harder A, Scherkenbeck J. Chimeric cyclodepsipeptides as mimetics for the anthelmintic PF1022A. Bioorg Med Chem Lett 2004;14:6129-2.

[18] Dutton FE, Nelson SJ. Synthesis of PF1022A, an anthelmintic cyclodepsipeptide. J Antibiot (Tokyo) 1994;47:1322-7.

[19] Dutton FE, Lee BH, Johnson SS, Coscarelli EM, Lee PH. Restricted conformation analogues of an anthelmintic cyclodepsipeptide. J Med Chem 2003;46:2057-73. 
[20] Lee BH, Dutton FE, Thompson DP, Thomas EM. Generation of a small library of cyclodepsipeptide PF1022A analogues using a cyclization-cleavage method with oxime resin. Bioorg Med Chem Lett 2002;12:353-6.

[21] Scherkenbeck J, Jeschke P, Harder A. PF1022A and related cyclodepsipeptides - a novel class of anthelmintics. Curr Top Med Chem 2002;2:759-77.

[22] Scherkenbeck J, Harder A, Plant A, Dyker H. PF1022A - a novel anthelmintic cyclooctadepsipeptide. Modification and exchange of the N-methyl leucine residues. Bioorg Med Chem Lett 1998;8:1035-0.

[23] Saeger B, Schmitt-Wrede HP, Dehnhardt M, Benten WPM, Krücken J, Harder A, v Samson-Himmelstjerna G, Wiegand H, Wunderlich F. Latrophilin-like receptor from the parasitic nematode Haemonchus contortus as target for the anthelmintic depsipeptide PF1022A. FASEB J 2001;15:1332-54

[24] Harder A, Schmitt-Wrede, Krücken J, Marinovski P, Wunderlich F, Willson J, et al. Cyclooctadepsipeptides - an anthelmintically active class of compounds exhibiting a novel mode of action. Int J Antimicrob Agents 2003;22:318-31.

[25] Harder A, Holden-Dye L, Walker R, Wunderlich F. Mechanisms of action of emodepside. Parasitol Res 2005;97:S1-S10.

[26] Harder A, von Samson-Himmelstjerna G. Cyclooctadepsipeptides - a new class of anthelmintically active compounds. Parasitol Res 2002;88:481-8.

[27] Chen W, Terada M, Cheng JT. Characterization of subtypes of gamma-aminobutyric acid receptors in an Ascaris muscle preparation by binding assay and binding of PF1022A, a new anthelmintic, on the receptor. Parasitol Res 1996;82:97-101.

[28] Gessner G, Meder S, Rink T, Boheim G, Harder A, Jeschke P, et al. Ionophore and anthelmintic activity of PF1022A, a cyclooctadepsipeptide, are not related. Pestic Sci 1996;48:399-407. 
[29] Zhang L, Yan K, Zhang Y, Huang R, Bian J, Zheng C, et al. High-throughput synergy screening identifies microbial metabolites as combination agents for the treatment of fungal infections. Proc Natl Acad Sci 2007;104:4606-11.

[30] Fukuda T, Arai M, Yamaguchi Y, Masuma R, Tomoda H, Omura S. New beauvericins, potentiators of antifungal miconazole activity, produced by Beauveria sp. FKI-1366. Taxonomy, fermentation, isolation and biological properties. J Antibiot 2004;57:110-6.

[31] Dornetshuber R, Heffeter P, Kamyar M, Peterbauer T, Berger W, Lemmens-Gruber R. Enniatin induces apoptosis and exerts p53-dependent cytostatic and p53-independent cytotoxic activities against human cancer cells. Chem Res Toxicol 2007;20:465-73.

[32] Lin HI, Lee YJ, Chen BF, Tsai MC, Lu JL, Chou CJ, et al. Involvement of Bcl-family, cytochrome c and caspase 3 in induction of apoptosis by beauvericin in human non-small cell lung cancer cells. Cancer Lett 2005;239:248-59.

[33] Jow GM, Chou CJ, Chen BF, Tsai JH. Beauvericin induces cytotoxic effects in human acute lymphoblastic leukemia cells through cytochrome c release, caspase 3 activation: the causative role of calcium. Cancer Lett 2004;216:165-73.

[34] Zhan J, Burns AM, Liu MX, Faeth SH, Gunatilaka AAL. Search for cell motility and angiogenesis inhibitors with potential anticancer activity: beauvericin and other constituents of two endophytic strains of Fusarium oxysporum. J Nat Prod 2007;70:22732.

[35] Jeschke P, Benet-Buchholz J, Harder A, Etzel W, Schindler M, Gau W, et al. Synthesis and anthelmintic activity of substituted (R)-phenyllactic acid containing cyclohexadepsipeptides. Bioorg Med Chem Lett 2006;16:4410-5.

[36] Shen DW, Cardarelli C, Hwang J, Cornwell M, Richert N, Ishii S, Pastan I, Gottesman MM (1986). Multiple drug-resistant human KB carcinoma cells independently selected 
for high-level resistance to colchicine, adriamycin, or vinblastine show changes in expression of specific proteins. J Biol Chem 1986;261:7762-70.

[37] Bunz F, Fauth C, Speicher MR, Dutriaux A, Sedivy JM, Kinzler KW, et al. Targeted inactivation of p53 in human cells does not result in aneuploidy. Cancer Res 2002;62:1129-33.

[38] Waldman T, Kinzler KW, Vogelstein B. p21 is necessary for the p53-mediated G1 arrest in human cancer cells. Cancer Res 1995;55:5187-90.

[39] Zhang L, Yu J, Park BH, Kinzler KW, Vogelstein B. Role of BAX in the apoptotic response to anticancer agents. Science 2000;290:989-92.

[40] Kamyar MR, Rawnduzi P, Studenik C, Kouri K, Lemmens-Gruber R. Investigation of the electrophysiological properties of enniatin. Arch Biochem Biophys 2004;429:215-23.

[41] Khom S, Baburin I, Timin EN, Hohaus A, Sieghart W, Hering S. Pharmacological properties of $\mathrm{GABA}_{\mathrm{A}}$ receptors containing gammal subunits. Mol Pharmacol 2006;69: $640-9$.

[42] Methfessel C, Witzemann V, Takahashi T, Mishina M, Numa S, Sakmann B. Patch clamp measurements on Xenopus laevis oocytes: currents through endogenous channels and implanted acetylcholine receptor and sodium channels. Pflugers Arch 1986;407: $577-88$

[43] Baburin I, Beyl S, Hering S. Automated fast perfusion of Xenopus oocytes for drug screening. Pflugers Arch 2006;453: 117-23.

[44] Heffeter P, Jakupec MA, Körner W, Chiba P, Pirker C, Dornetshuber R, Elbling L, Sutterlüty H, Micksche M, Keppler BK, Berger W. Multidrug-resistant cancder cells are preferential targets of the new antineoplastic lanthanum compound KP772 (FFC24). Biochem Pharmacol 2007;73:1873-86. 
[45] Martin RJ, Harder A, Londerhausen M, Jeschke P. Anthelmintic actions of the cyclic depsipeptide PF1022A and its electrophysiological effects on muscle cells of Ascaris suum. Pest Sci 1996;48:343-9.

[46] Kouri K, Duchen MR, Lemmens-Gruber R. Effects of beauvericin on the metabolic state and ionic homeostasis of ventricular myocytes of the guinea pig. Chem Res Toxicol 2005;18:1661-8.

[47] Kamyar MR, Kouri K, Rawnduzi P, Studenik C, Lemmens-Gruber R. Effects of moniliformin in presence of cyclohexadepsipeptides on isolated mammalian tissue and cells. Toxicol In Vitro 2006;20:1284-91.

[48] Kouri K, Lemmens M, Lemmens-Gruber R. Beauvericin induced channels in ventricular myocytes and artificial membranes. Biochim Biophys Acta 2003;1609:203-10.

[49] Ivanov VT, Evstratov AV, Sumskaya LV, Melnik EI, Chumburidze TS, Portnova SL, Balashova TA, Ovchinnikov YA. Sandwich complexes as a functional form of the enniatin ionophores. FEBS Letters 1973;36:65-71.

[50] Ovchinnikov YA, Ivanov VT, Evstratov AV, Mikhaleva II, Bystrov VF, Portnova SL, Balashova TA, Meshcheryakova EN, Tulchinsky VM. The enniatin ionophores. Conformation and ion binding properties. Int J Peptide Protein Res 1974;6:465-498

[51] Fadeel B, Orrenius S. Apoptosis: a basic biological phenomenon with wide-ranging implications in human disease. J Int Med 2005;258:479-517.

[52] Los M, Mozoluk M, Ferrari D, Stepczynska A, Stroh C, Renz A, et al. Activation and caspase-mediated inhibition of PARP: a molecular switch between fibroblast necrosis and apoptosis in death receptor signalling. Mol Biol Cell 2002;13:978-88.

[53] Tang Y, Chen YW, Jow GM, Chou CJ, Jeng CJ. Beauvericin activates $\mathrm{Ca}^{2+}$-activated $\mathrm{Cl}^{-}$ currents and induces cell deaths in Xenopus oocytes via influx of extracellular $\mathrm{Ca}^{2+}$. Chem Res Toxicol 2005;18:825-33. 
Figure legends:

Fig. 1: Pore-forming activity and changes in intracellular ion concentrations. In (A) typical recordings of a $\mathrm{Ca}^{2+}$ current from an inside-out patch are shown. The dashed line marks the closed state "c"; downward deflections indicate channel openings. The holding potential was held at $-60 \mathrm{mV}$. The upper trace 1 shows a control recording without openings. Traces 2 and 3 represent single and multiple channel openings in presence of 1 and $10 \mu \mathrm{M}$ PF1022A, respectively. The small increase in intracellular $\mathrm{Ca}^{2+}$ concentration (expressed as ratio $\left.\mathrm{F}_{340 \mathrm{~nm}} / \mathrm{F}_{380 \mathrm{~nm}}\right)$ caused by $100 \mu \mathrm{M}$ PF1022A (C) is shown for three representative cells in comparison to $100 \mu \mathrm{M}$ ionomycin (B) (note the difference in scale on the ordinate). At $10 \mu \mathrm{M}$ no changes in $\left[\mathrm{Ca}^{2+}\right]_{\mathrm{i}}$ were observed (data not shown). The effect on intracellular $\mathrm{K}^{+}$ concentration is shown for $100 \mu \mathrm{M}$ PF1022A (E) and $100 \mu \mathrm{M}$ valinomycin (D) for two representative cells each.

Fig. 2: Concentration-dependent effect on cell growth is demonstrated in KB-3-1 cells after exposure to PF1022A for 24, $48 \mathrm{~h}$ and $72 \mathrm{~h}$. After the respective treatment durations, drug solution was replaced by $100 \mu 1$ MTT solution and viability was measured by a microplate reader, set at $450 \mathrm{~nm}$ with $620 \mathrm{~nm}$ as reference to reduce unspecific background values. All experiments were performed at least twice in triplicates. ${ }^{(a)}$ Cell growth-stimulating and ${ }^{(b)}$ cytotoxic effects were significantly $(*, * *, * * *: \mathrm{P}<0.05,<0.01,<0.001$, respectively) different to untreated control (Student's t-test).

Fig. 3: (A, B) Nuclei of KB-3-1 cells were stained with DAPI, classified (in interphase, mitotic, and apoptotic) and counted. Means \pm SD were calculated from at least 500 nuclei from three independent experiments. ${ }^{*}, * *$, significant $(\mathrm{P}<0.05,<0.01$, respectively $)$ 
difference between PF1022A-treated and -untreated cells was calculated using the Student's ttest. (C) Changes in the mitochondrial membrane potential were measured after $24 \mathrm{~h}$ and $48 \mathrm{~h}$ of PF1022A treatment using the fluorescent dye JC-1. Percentages of apoptotic (green fluorescent, FL-1) cells, located in the right lower quarter, are indicated at the left bottom.

Fig. 4 PI staining and FACS analyses were performed on KB-3-1 cells after $24 \mathrm{~h}$ and $48 \mathrm{~h}$ PF1022A exposure at the indicated drug concentrations. Percentages of cells in the $G_{0} / G_{1}, S$, and $\mathrm{G}_{2} / \mathrm{M}$ phases of the cell cycle as well as apoptotic cells are indicated. *, **, significantly $(\mathrm{P}<0.05,<0.01$, respectively) different to untreated cells (Student's t-test). 
Fig. 1
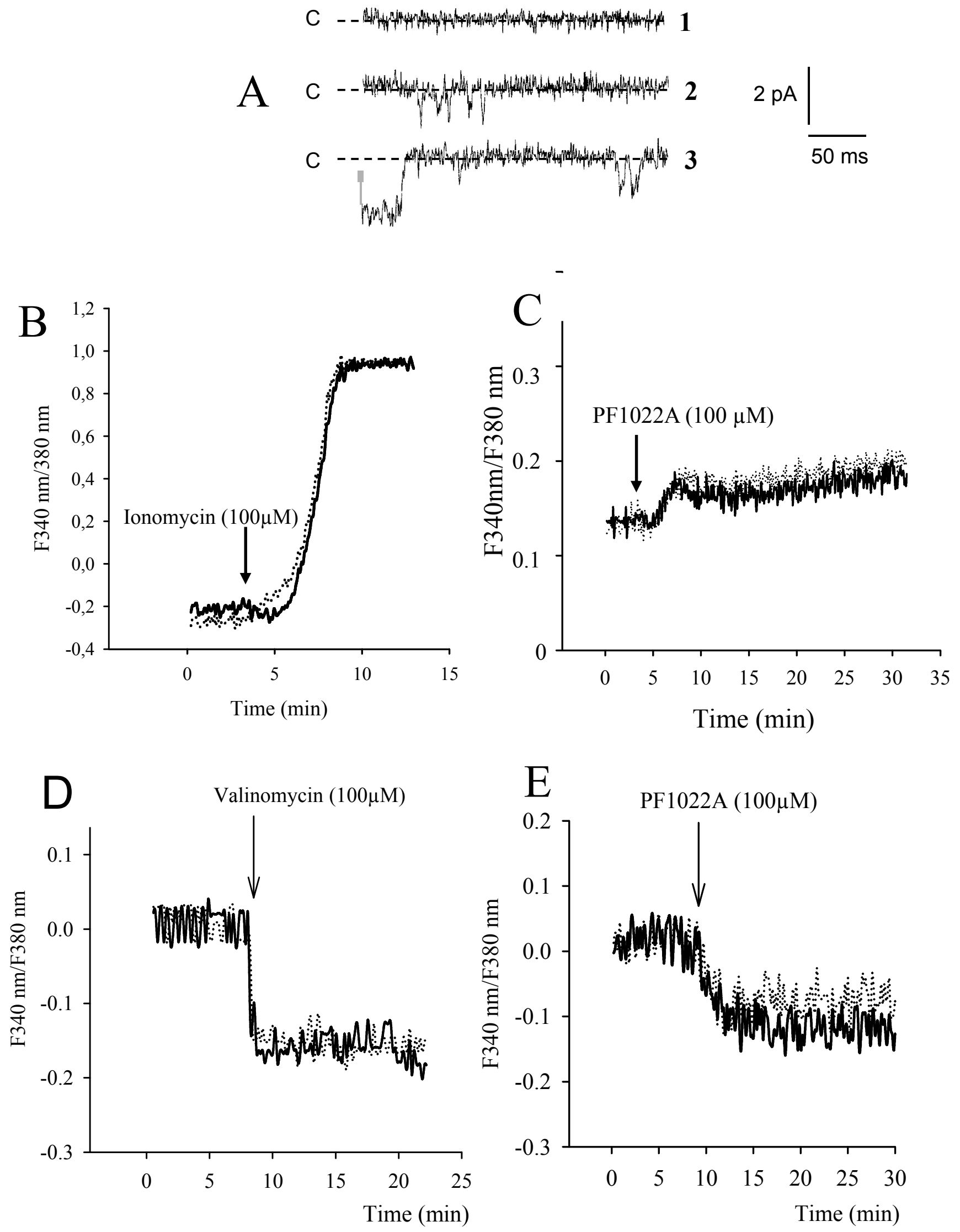
Fig. 2

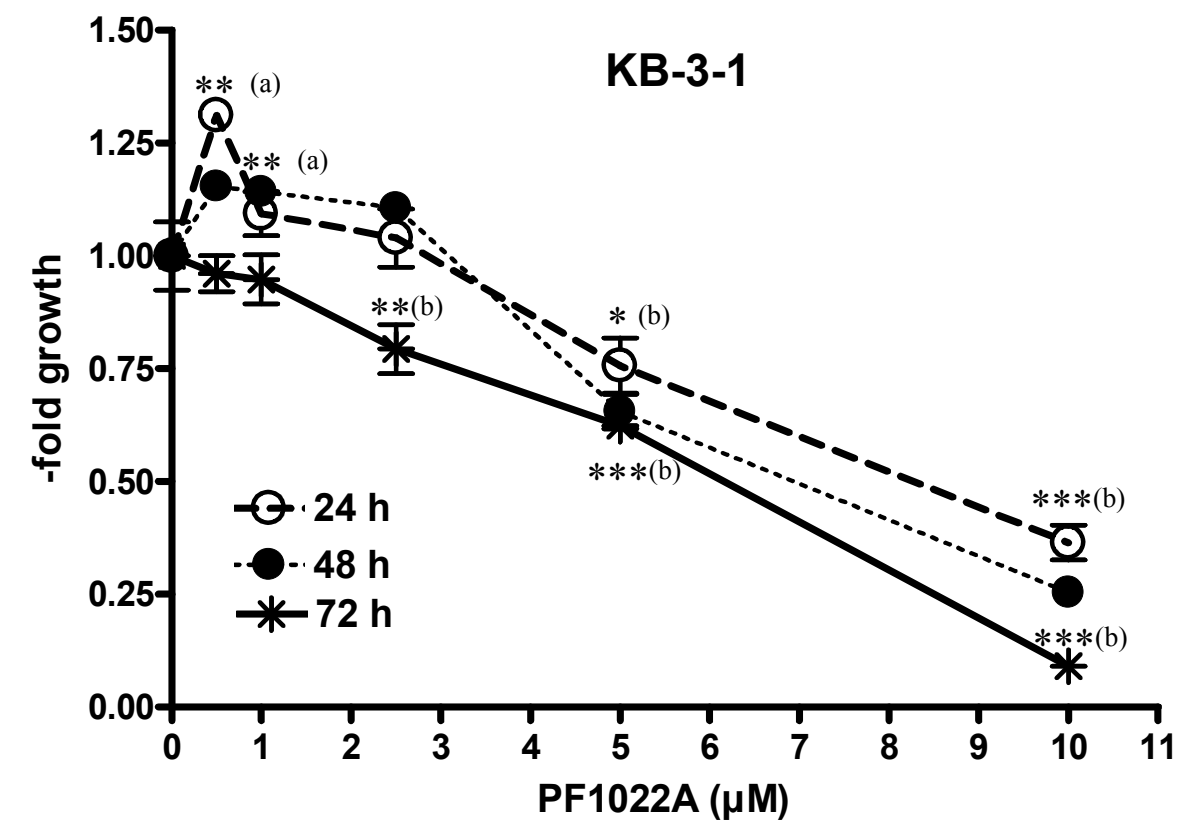


Fig. 3

A
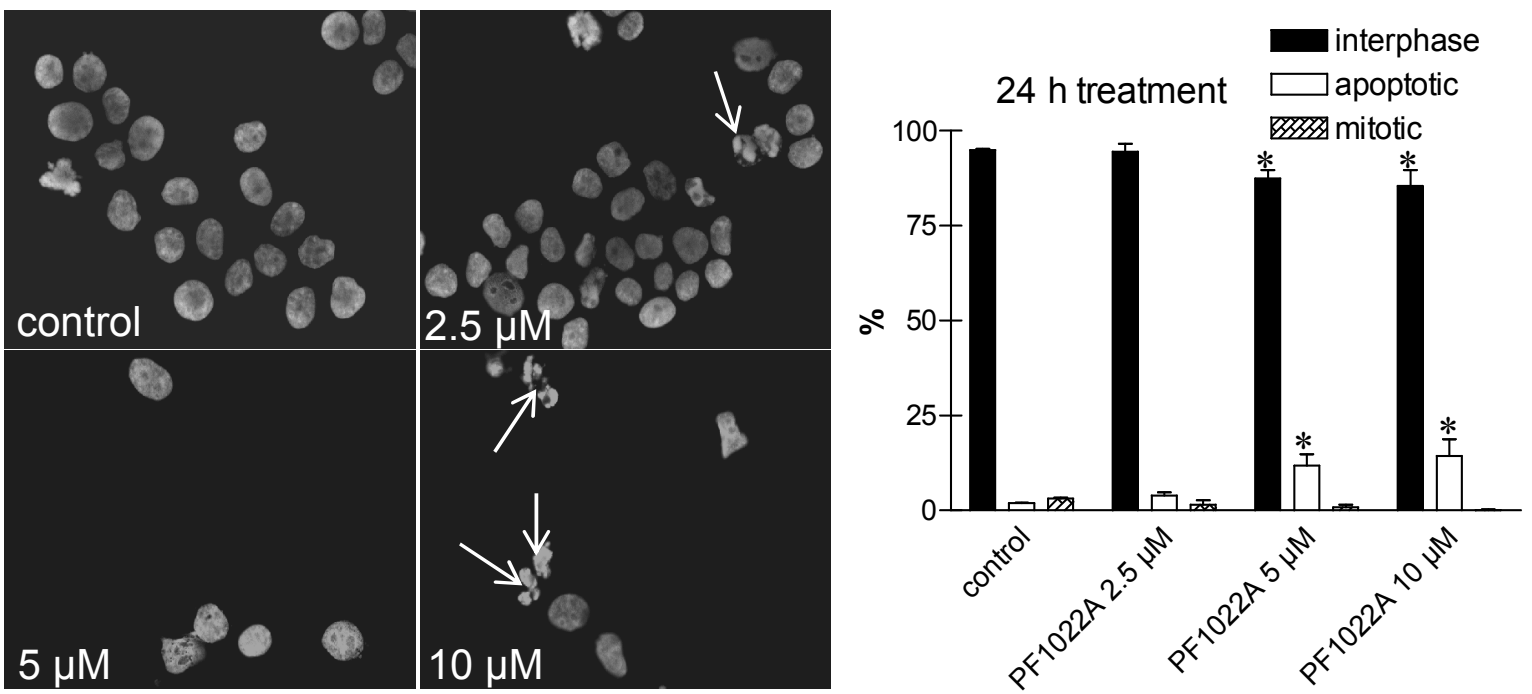

B
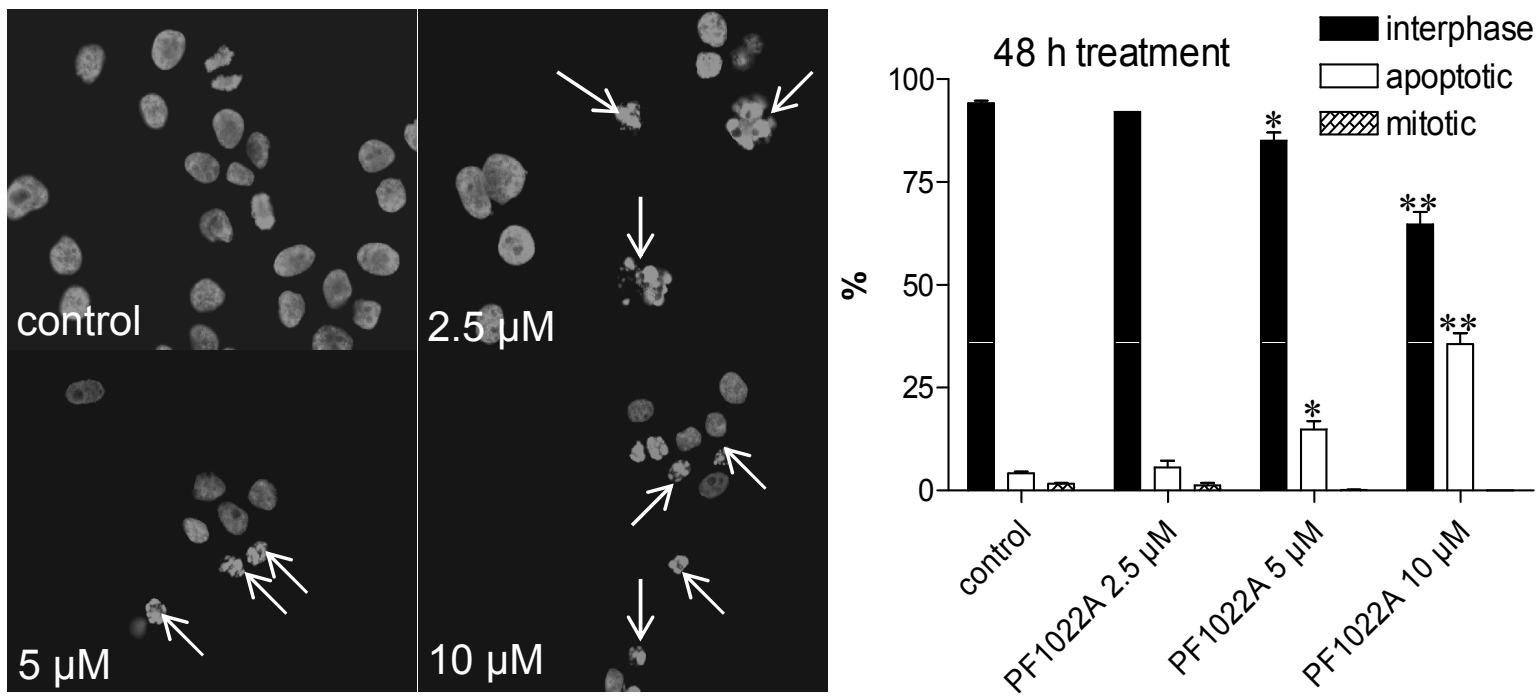

C
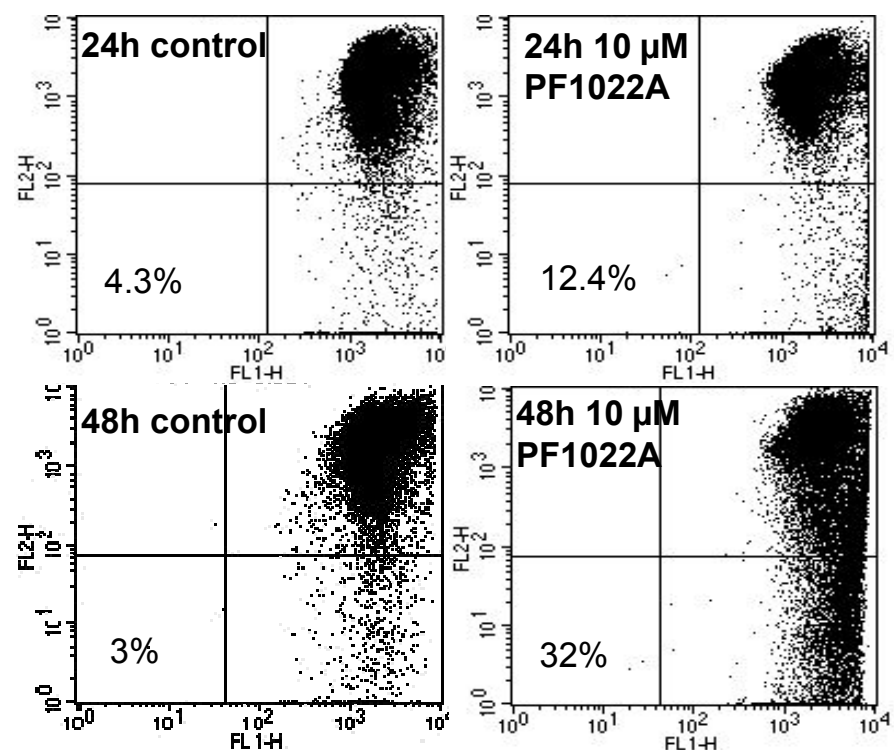
Fig. 4
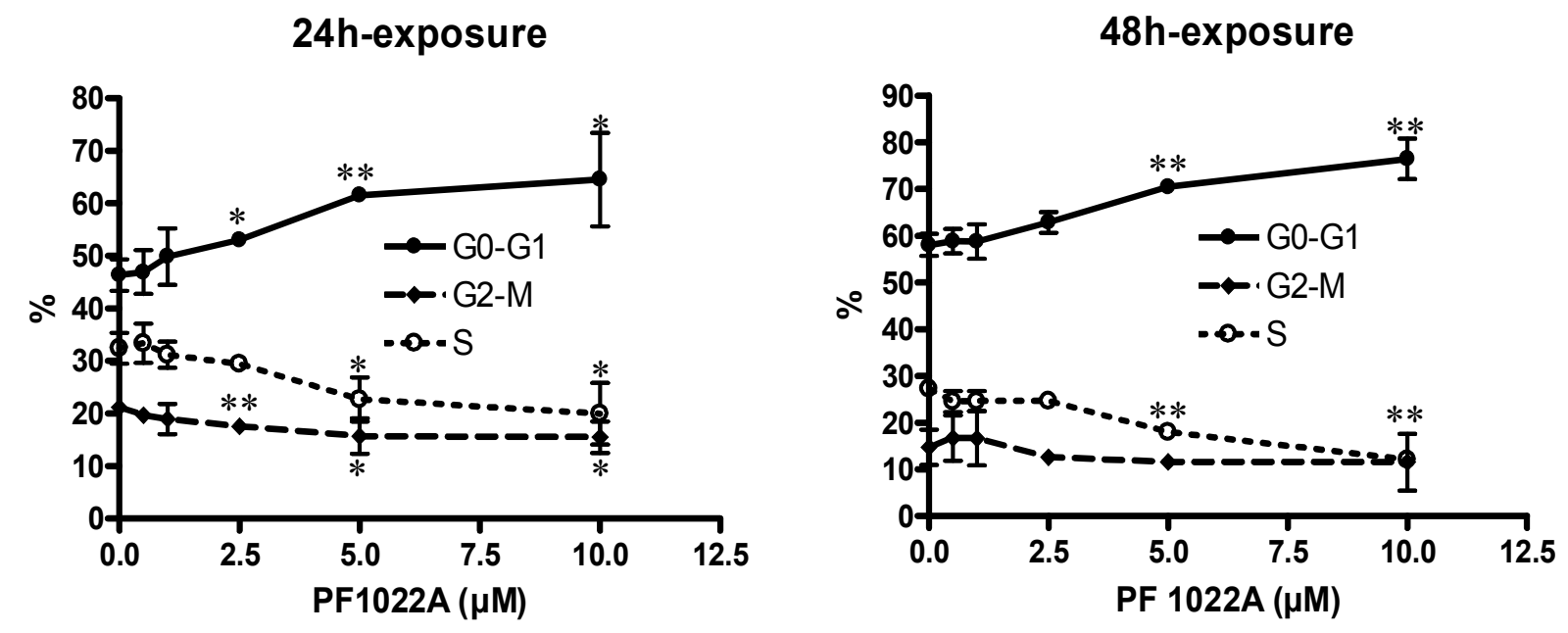
Table 1: Impact of apoptosis- and cell cycle-regulating proteins p53, p21, Bax, and Bcl-2 on PF1022A-induced cell death. $\mathrm{IC}_{50}$ values $(\mu \mathrm{M})$ for the time-dependent cytotoxic effect of PF1022A are given.

\begin{tabular}{|l|c|c|}
\hline \multicolumn{1}{|c|}{ Cell line } & $\mathbf{4 8 ~ h}$ & $\mathbf{7 2} \mathbf{~ h}$ \\
\hline HCT 116 p53 (+/+) & $8.4 \pm 0.1$ & $7.5 \pm 0.1$ \\
\hline HCT 116 p53 (-/-) & $9.6 \pm 0.3$ & $9.1 \pm 0.1$ \\
\hline HCT 116 bax (+/+) & $7.4 \pm 0.3$ & $7.1 \pm 0.1$ \\
\hline HCT 116 bax (-/-) & $9.5 \pm 0.1$ & $8.2 \pm 0.1$ \\
\hline HCT 116 p21 (+/+) & $9.4 \pm 0.1$ & $8.2 \pm 0.1$ \\
\hline HCT 116 p21 (-/-) & $6.0 \pm 0.1$ & $4.6 \pm 0.1$ \\
\hline A549/Bcl-2 & $7.5 \pm 0.1$ & $4.3 \pm 0.2$ \\
\hline A549/vc & $7.3 \pm 0.1$ & $4.6 \pm 0.1$ \\
\hline
\end{tabular}


Cytotoxicity of the ionophoric cyclooctadepsipeptide PF1022A is induced by apoptosis via the mitochondrial pathway and cell cycle blockade in $\mathrm{G}_{0} / \mathrm{G}_{1}$ phase at concentrations higher than those used in anthelmintic treatment.
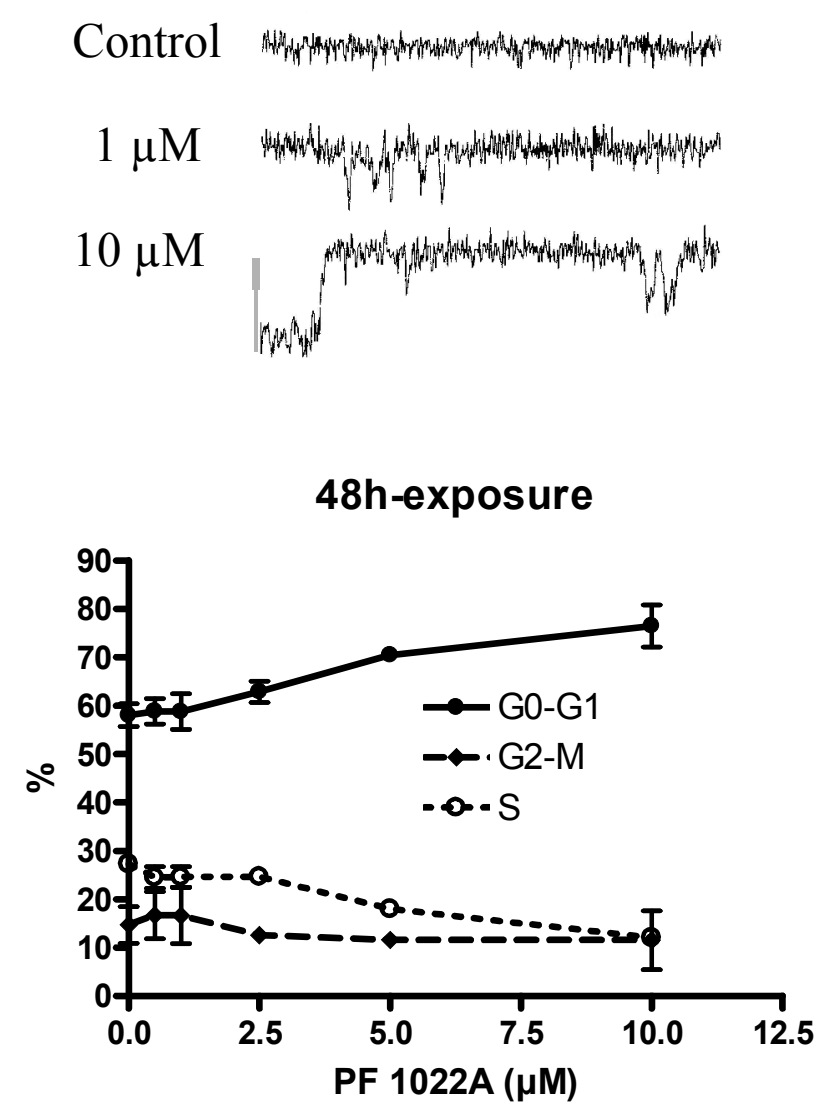